I State Univeristy of Rio de Janeiro, Institute of Social and

Political Studies (IESP/UERJ), Rio de Janeiro, RJ, Brazil

acardoso@iesp.uerj.br

Adalberto Cardoso'

\title{
INFORMALITY AND PUBLIC POLICIES TO OVERCOME IT. THE CASE OF BRAZIL
}

\section{INTRODUCTION}

Public policies designed to combat informality often build upon incomplete diagnoses of informality and its role in the structuring of economic and social relations in countries in which it at times occupies the majority of the economically active population. In Latin American countries, informal workers, on average, arguably work more, earn less, toil in unsafe conditions (informal labor is often linked to illegal activities), are in vulnerable positions in the labor market, since their businesses can swiftly be lost, become embroiled in illegal networks and/or police corruption, have worse living conditions, etc., all comparing unfavorably to formal jobs or jobs protected by the State or by market regulation institutions (whether labor or business related). In this context, combatting informality is tantamount to combatting the social vulnerability of a significant portion of the working masses.

This rapid listing of some of the dimensions of this vulnerability makes it clear, however, that combatting informality goes beyond the simple idea of "formalizing the informal", which has been the main line of action followed recently by the International Labour Office, for example. ${ }^{\mathrm{I}}$ Bringing into the State's view informal activity through its formalization is important as it opens the doors to public regulation and, above all, social protection. But policies must build perspectives that are adequate to the phenomena they are dealing with. 
Brazil, in line with other countries in the region, and in response to the recommendations of international agencies (such as the International Labor Organization and the World Bank), has been adopting policies that aim at rendering formality more attractive to workers that have so far shunned formality. These measures have been varied. They include the reduction of costs incurred by formalization, the creation of incentives for formalization and permanence in the formal market, and, to a lesser degree, increasing the costs of informality. They also include other policies that are not necessarily aimed at formalization, but ultimately produce this result. Such is the case of income distribution policies, which, by affecting overall salaries, increase available income, and thus the consumption pattern of the poorer segments of the population, thus energizing typically informal marketplaces that usually depend on this type of popular consumption. Such is also the case of investments in infrastructure, which generate a large number of formal employment in civil construction, a sector that is typically informal. ${ }^{2}$

In this study, I intend to discuss some of these policies, their design and eventual impact on the reduction of informality. Before, however, I return to the debate on informality in order to advance the idea that it is one among other social forms of labor, typical of countries in which the regulated and protected labor market never generated enough work for all, leaving successive generations no other choice than to create their own mechanisms to obtain their means of living, generally in environments in which everything is informal: the occupation of urban land, the construction of homes, access to urban infra-structure (such as electric power, water, sewage and others), interpersonal relations and the relationship with public institutions (generally the police, and usually marked by violence) and sociability in general. In Latin American countries, informally securing means of living is an integral part of the life styles of a significant portion of the population, to whom the State appears (and was historically constructed) as a complex institutional entity that raises suspicion and for many is better kept at bay. "Formalizing the informal" requires, in this context, broad-ranging intervention aiming at formalizing the very way of life of entire parcels of the population that extract sustenance from their work.

\section{THE ETERNAL RETURN TO THE INFORMAL}

What should be understood by informality? The term (which many consider a concept) has a long history, summarized through time by an assortment of authors, among them Barbosa (2OII), a competent venture into the field. He surveys the metamorphoses of the concept from the time of its dissemination with the publication of an ILO report on the economy of Kenya, dated I972, which most consider as the starting point of the trajectory of this "quasiconcept" (as Machado da Silva, 2002, would rather frame it) in worldwide social 
theory and research (ILO, I972). In the Kenya report and in Keith Hart's seminal text (I973), "informality" was constructed as a category in dialogue with the structural transformations under way in peripheral countries in the capitalist system, and served to render intelligible an urban world in accelerated transformation, as the result of intense rural migration to the cities, where the salaried job market was far too small to absorb all incoming workers.

This is not the place to retrace the history of the concept; I would simply like to remark that there are a plethora of definitions, which not always refer to the same phenomena. In Filgueiras et al. (2004:2 I I), for example, we read the following definition:

the several concepts of informality [comprise], in the aggregate, all productive
activities that are not constituted as forms of capitalistic production, for they
do not employ salaried work and do not follow the logic of the pursuit of profit
and the accumulation of capital; or, alternatively, and in a broader sense, be-
cause they encompass, also in the aggregate, all economic activities, capitalis-
tic or otherwise, that are not regulated by the legal norms in effect and that are
socially accepted.

The first part of the definition alludes to the more deep-seated structures of the capitalist order, while the second one refers to its legal and regulatory framework (also see Telles, 2010). The ILO's definition, laid out in I972, is closer to the first one, while the second one reflects the redefinition that the ILO itself applied to its concept of informality in 2002, with the goal of including informal (and often illegal) practices that are also found in wealthier nations (ILO, 2002), caused by new forms of flexibilization and the deterioration of the use of labor as a result of economic globalization.

Both dimensions of the definition are often intertwined in theoretical discussions and in their use in empirical research. Dedecca (2007), however, calls the first "the informal sector" (Oliveira, I972 and I987; Souza, I980; and Cacciamali, I 982 would follow suit) and the second one simply "informality," making it clear that it is necessary to distinguish non-agrarian economic practices with the goal of guaranteeing the survival of those involved (which, therefore, could not be called typically capitalistic), from forms of binding the worker to the productive capitalist system, characterized by precarious conditions and the lack of protection, something Cacciamali (2000), Sassen (2000) and also Oliveira (20I I) would agree with. Cacciamali (2000) calls the phenomenon a "process of informality" while the latter two use the term "new informality," both in order to distinguish it from the "informal sector" (in its traditional meaning of autonomous activities for the worker's survival) and to draw attention to new forms of the use of labor in globalized and flexible capitalism.

These approaches, although often very distinct in their analytical consequences, assume at least one point in common: the existence of an "informal sector" or a (theoretical and empirical) "environment" in the economic 
order that cannot be reduced to the other which serves as the normative referent in the definition, i.e. the "formal sector." Even if, after Oliveira (I972) or Tokman and Souza (I976), it is no longer possible to deal with the two "worlds" as poles, or as static and separate opposites, one modern and capitalist, and the other lagging and not fully capitalist (or even pre-capitalist), nevertheless what lies in the horizon is the idea of segmented labor markets, determined by distinct logics, that is, distinct forms of circulation of people through existing positions, distinct forms of compensating work, valuing capital and so on.

The definition proposed by the anthropologist Keith Hart (in a text published in 1973, but which served as a reference for the ILO mission in Kenya culminating in the abovementioned report ${ }^{3}$ ) was more complex and multi-dimensional. For Hart there were potential sources (or opportunities) of income in peripheral economies such as Ghana, the object of his study: one in a sector in which opportunities of income are formal (in the public or private sector), another one in which opportunities are informal, yet legal (he uses the term legitimate, such as small businesses and services in general), and a third one, in which the opportunities are informal and illegal (such as prostitution and smuggling, and the term used is illegitimate (Hart, I973: 69). These "sectors" are not static, and each one in itself is very heterogeneous. Furthermore, a large number of people had occupations (or undertook paid activities) in more than one or even in all three, in combinations that led to extended working hours, despite low remuneration. Hart himself, later commenting on his definition, would go on to insist that "there was never a moment in which I identified the 'informal economy' as a place, a class, or even with people" (Hart, 2006: 25), despite advancing, in the end of the article, forms of studying the relationship between the "two sectors."

Without dwelling upon the details of the discussion that followed these works and the dissemination of the concept of informality through the world (and the related terms "the informal sector" and the "informal economy") the relevant point for this study is the idea, pregnant with analytical possibilities, of opportunities of income available to workers in economies that are marked by an excess of available labor force, often the result of accelerated urban growth that is not accompanied by the growth of structured (or formal) sectors of the economy, incapable of generating enough jobs to absorb all those who have migrated to cities. This was the reality found by Hart in Ghana and by the ILO mission in Kenya, and this was (and still is) the reality of the majority of Latin American countries, to where the concept migrated in the I97os (replacing notions such as the "culture of poverty," "liminarity," and, most of all "marginality," all of which have been recurrent in the academic debate concerning urban overpopulation in the I96os and part of the I970s4) responsible for producing important analyses of the specificity of peripheral capitalist economies (Nun, 200I; Tokman, 2004; Lautier, 2004; Coletto, 2010). 
Hart's perspective was that of the anthropologist, interested, first and foremost, in the mechanisms of incorporation of migrants into the urban world, and their living conditions, particularly their capacity of generating enough income to ensure the survival of individuals and families. This starting point is rather different than the one traditionally adopted in the economic analyses conducted by the institution the research of which Hart inspired (the ILO), that adopted the point of view of the firm to suggest the employment and development policies for Third World countries. Hart assumed the perspective of people in search of economic opportunities.

In fact, economic theory traditionally utilizes the terms supply and demand to designate those supplying and demanding labor. Demand for labor, labor supply. The point of view assumed is that of the demanding side, namely, the firm, that detains the decision-making power over investments, which, whether small or large, require more or less labor force, more or less technology, more or less financial resources, public policies of this or that nature, etc. The starting point is the entrepreneurial capitalist who sets in motion the economy, workers and the institutions of the State in the pursuit for profit. A legitimate point of view, to be sure, capable of producing relevant knowledge concerning the economy, state institutions and life opportunities. Yet insufficient to understand the many dimensions of informality, and the actions necessary to face them.

From the point of view of a sociology of the labor market, the one adopted here, those who demand (or seek) occupational and social insertion, and also income opportunities, are workers, or people who bring to the economic order their will to provide labor. 5 The economic and social order is perceived as a set of opportunities and restrictions to access positions within its structure. Men or women, therefore, are in search of social and economic insertion, and these will not always be associated with (or conditioned by) the supply of positions on the part of those who control the means of production and circulation of wealth and services (private and public). This perspective is still pregnant of theoretical and empirical consequences that can help to renovate the horizon of our comprehension of the social forms of labor in Brazil and Latin America, and especially "informality."

People of a certain age and after undergoing determined identity transitions (usually through the educational system) become part of the workforce. This does not mean they are in the labor market. They simply become available to employ their physical and mental faculties in this environment where the production of goods or the provision of services that support this production (in commercial or financial transactions, or in personal or family-oriented services that support individual and collective life) occurs.

From the point of view of people who become available for work, as said, the world presents itself as a complex and often opaque set of opportunities 
leading to occupational insertion (and its entrance barriers), and the effective realization of the potential that is the availability of labor will be a function of a set of determinants only partly (often a minute part) controlled by individuals themselves.

From the perspective of the economic structure, there is the effective supply of jobs, which for the isolated worker may not always seem as what it is, i.e. the aggregate result of business and government decisions (public employment is always important), a figure the isolated worker entirely ignores or, if not, can do little about in terms of determining its direction, size, scope or duration in time. Unless the person in question is the daughter of a precautious capitalist, who has ordered the structure of opportunities of his offspring so that she could choose between submitting to the decision of others or becoming someone to whom others will submit their disposition to work, for example, following in the footsteps of the progenitor, for the majority of workers the only option is to locate, within the structure of opportunities, those that match their qualifications, aspirations, desires, needs and urgencies, which are, moreover, shared with others in similar conditions, thereby making it possible to approach the question in terms of social classes or collectives that share the same social trajectory probabilities in environments that are only tenuously within their control. ${ }^{6}$

This means that the structure of supply of opportunities of occupational insertion is largely independent from the worker who is seeking insertion. The supply of labor opportunities is exogenous to most people (the outcome of decisions made by others which, in the aggregate, constitute economic activity and its history). However, and this is the main point, to some it can be endogenous.

Let us consider. Looking at the world from the point of view of someone who is seeking opportunities, there is the person who creates for herself the conditions of occupational insertion, not only as a capitalist (or artisanal or artistic) entrepreneur, but also as a liberal professional with enough resources to establish herself on her own (a dentist, a psychoanalyst, a doctor), or even as an autonomous worker that holds more or less capital (or entirely lacking capital), who "chooses" this type of social inscription because the objective structure of the supply of insertion opportunities is not viewed as such, experienced as such, or accepted as such, or does not accept the one demanding work as adequately qualified or is simply saturated in terms of the capacity to absorb more workers demanding positions.

The choice of one's own pathways, either creative and voluntary ones, or others that are compulsory as a result of the friction between what is offered by the social and economic structure and the worker's aspirations and actual labor skills, which may thwart or hinder access to existent position (also due to competition between those demanding jobs) is a central element 
determining life opportunities in Brazil and Latin America. There are not, nor has there ever been, enough salaried positions for all those who earn their income from labor. Salaried positions do not correspond to the aspirations and demands of all. Salaried work as a collective destiny is not a given for all. The supply of "good" positions (as if salaried, wage-earning work were "good") is not universal. Thus, not everything in the social and economic order presents itself as exogenously determined opportunities, or, more precisely, that which is thus given is not accessible to all, and a part of those who become part of the labor force will never even seek for social insertion according to the rules or conditions created by the order determined exogenously. In other words, not all will become a part of the labor market as such, since not all are willing to sell their labor to any employer.

Of course, as modernity is capitalist and commodity-driven, access to the basic means of living (and a reasonable amount of others) occurs through the market. To become socially integrated in a minimally autonomous fashion in a commodity-based environment means to achieve the material conditions to obtain or generate means of living in the market. The key word is, today, as much as when Hart wrote about Ghana, income. It provides access to means of living in the urban world. It provides access to the things that allow us to build our identity, including life styles; it provides us with social and cultural capital (Lin, 200I; Bourdieu, I977), which, in turn, makes it possible for us to fulfill our potential trajectories in the commodity-based world. ${ }^{8}$

The pursuit of the "mechanisms to obtain the means of living" unfolds in heterogeneous environments in which there are hierarchies that determine the supply of opportunities, and also hierarchies in terms of the capability to choose one's own means of obtaining income. In an environment in which salaried, wage-earning work never became universal, it is not a given that the State regulated salaried positions (and all its attendant rights) are a general aspiration. It is known that in situations of social vulnerability, if one could choose, one would choose protected work. ${ }^{9}$ But this aspiration does not always structure all life projects. The social and economic environment in which socialization occurs in Brazil is in fact constituted by the non-universality of salaried work, and therefore by the naturality of projects and aspirations to live according to one's own design - something that can be shared by the family as a whole or by a portion of their members. ${ }^{\text {I0 }}$ This occurs regardless of the desire of more or less well-being involved in this operation because, as shown by Santos (2006), the horizon of expectation for income is very narrow in Brazil. Life is by and large vulnerable and fragile, and inclusion by one's own efforts, when precariously realized, is compared to salaried positions that can be equally unstable and precarious, and also poorly paid. Thus, for a long time in Brazil the majority of social integration aspirations were built in environments where income expectations have been astonishingly low. ${ }^{11}$ 
This, obviously, curtails the idea that, at some point, it would be possible to "revolutionize" the "informal sector" with regulated salary-based labor. A considerable part of workers who are today self-employed would rather remain in such position, even with the perspective of a job, whether temporary or not. In the cost-benefit equation considering shifting between occupational opportunities, autonomy, "liberty," and the possibility of employing a family member, etc., can lead to a preference for informality, even if income levels remain lower. Indeed, as posited by Harvey (20I I), capitalism is capable of renovating in many ways its "primitive accumulation," and tends to occupy previously informal economic spaces every time entrepreneurs foresee profit, and those who were previously established in these spaces of accumulation will gradually be driven away. ${ }^{12}$ Nevertheless, they will, if possible, establish themselves in another space or in another activity maintaining the same characteristics, depending on factors such as age, gender, financial resources, etc.

The "option" for the informal can be the result of socially determined choices at very early ages, and - a very important aspect - is not a univocal class destiny. A significant part of young Brazilians drop out from school precociously, not always aware that this will limit their first choices, and occupational insertion will almost always lead to an adjustment of expectations to the objective conditions of competition with other more qualified workers. The adjustment will occur throughout their lives and, although most times workers are "chosen by their choices" (Bourdieu, I979), they will nurture the illusion that autonomy is a "choice" when "choosing" salaried work is no longer an option due to age or labor-related diseases or outdated qualification, etc. The trajectory "school drop-out à first precarious job à adjustment of occupational expectation à return to school à more precarious jobs à self-employed insertion" is typical in Brazil, i.e. it tells the story of a substantial portion of older workers.

Yet, it is not a univocal class destiny because Brazilian families are made up of the amalgam of configurations that their members constitute as they enter the fray to achieve or construct their means of living. And also as, in many cases, there is the possibility of some being formally employed, others working informally, upwards social mobility of some, declassification or "defiliation" of many others (Castel, I998), etc., such that the probability of life trajectories, albeit shared by extensive collectives of workers, are shared in their profound heterogeneity and complexity. If all, starting at a certain age, are part of the workforce, not all will be part of labor market, or at some point will be excluded.

In sum, hard pressed by the need to obtain the means of living in a commodity-based social order, workers demand or construct opportunities of occupational insertion, and informal labor, self-employment, or unregulated work figure among the available options. Options that are, historically, part of 
the horizon of possibility of social inscription of people who live from their work in environments often characterized by extreme vulnerability and precariousness, leading to a "natural" and often precocious choice for informality. And informality, whether chosen or compulsory, will never be "pure," since it will share the social space of opportunities with other social forms of labor, whether those achieved by workers in search for means of living or those exogenously offered by the economic order.

This means that, from the point of view of those demanding positions in the economic and social structure, social insertion in the realm of "informality" can be: (I) the outcome of more or less vulnerable life trajectories; (II) a "choice" that results from a daily adjustment of expectations to objective conditions; (III) an effective choice taken in an environment of socialization constituted by a hierarchy-based and heterogeneous set of opportunities and limits of social insertion, among them "informality"; (IV) an opportunity (an inheritance, an invitation from a business partner, etc.).

It is possible to broaden this categorization, subdivide it, render it more complex, but most trajectories that end or are born or are created in the "informal" can be framed within it. ${ }^{13}$ And it denotes that insertion in "informal" spaces is not only adaptive, in the sense of adaptation of the qualification and longings of workers to the supply of precarious positions by others (public or private jobs). It is often also creative, in the sense that people must produce, alone or in association with family or friends, the conditions to secure means of living.

In addition, inscriptions (I) and (II), above, indicate that, for a significant part of Brazilian workers, the dream of being a part of the world of formal labor rights and its attendant social protection, thereby leaving informality, is the remnant of the past and was never realized, ${ }^{14}$ sometimes by will of the worker. Thus, any policy aimed at taming informality must acknowledge an structural aspect of the Brazilian (and also Latin American) process of capitalist modernization: there are several "lost generations" in the course of the last decades, that accumulated a generational deficit of workers that will never enjoy the coverage of formal salaried work. And, in younger generations, there is a non-negligible proportion of those who will not find protected work, due to any one of the four reasons mentioned above. ${ }^{16}$

This also means, as previously suggested by Nun (1969) and, afterwards by Oliveira (I972 and I987), that the "informal sector" is not a "cushion" or a "reservoir" of labor for the "formal sector," neither a set of economic and social practices that will be "revolutionized" as capitalism makes inroads into the country. In other words, regardless of the degree of structuring or formalization of labor in Brazil (our next topic), there will always be a resistant and significant fringe of social and economic relations that specialists will continue dubbing "informal." This conclusion is contained in the pioneering stud- 
ies of Oliveira (I972), Tokman \& Souza (I976) and also Cacciamali (I982), three of the most important theoretical references on the subject in Latin America.

With the exception, however, of Oliveira (1972), and as argued by Machado da Silva (2002), the "quasi-concept" of informality was coined and thrived in a political and intellectual atmosphere (the I970s) that cultivated ideas that stemmed from the theories of modernization, and the trajectory that followed the pattern urbanization/industrialization/salaried work/full employment was conceived as typical of capitalist societies, and hence, sooner or later, the inevitable fate of "developing" countries. Informality (and the "informal sector") would cease to exist the moment countries reached full development. The crises of the I980s, the de-industrialization of the countries where capitalism originated, the relative weakening of the Welfare State and its policies of social protection, employment and the flexibilization of labor (especially top-to-bottom outsourcing and subcontracting in value chains) pulled the rug from under the belief that development would result in the overcoming of the "informal" and globalization ultimately helped generalize, in the developed world, practices previously thought to be exclusive to underdevelopment, such as precarious, atypical work that is not covered by social protection. ${ }^{15}$

\section{RECENT EVOLUTION OF INFORMALITY IN THE BRAZILIAN LABOR MARKET}

In Brazil, informality is traditionally estimated based on two main indicators, collected from household surveys: the proportion of self-employed or autonomous workers that do not contribute to social security; and the proportion of salaried workers that do not have signed labor cards. ${ }^{17}$ Public policies aimed at the reduction of informality to be discussed ahead, adopted as an eligibility criterion for tax breaks the firm's turnover (with upper thresholds that vary according to each policy) and, in at least one case, the employment of labor (one occupation offered). Therefore, public policies acknowledge that there are informal employers, and in fact they are the main target, as we shall see.

Based on this, I propose a refinement of the traditional rate used in Brazil, so as to include, in addition to salaried workers without signed labor cards and self-employed, non-contributing workers, employers with only one occupied worker who also does not contribute towards social security. Using these criteria, the rate of informality in Brazil has been dropping consistently since I999, being that after 2003, this drop has accelerated. It must also be observed that, although the rate declines (meaning that more formal than informal occupations are being generated during the analyzed period), in absolute numbers informal workers also grow consistently until 2007, when their number reached 37.4 million, then dropping to 35.5 million in 2013 (a difference of almost 2 million positions). Therefore, there has been an effective decline in the proportion of informal employers and entrepreneurs in Brazil, 
however until 2007 this decline was due, moreover, to the generating of formal occupations in a superior rate than informal occupations. Since then the drop has also been the result, assumedly, of the "formalization of the informal" since informality drops in absolute terms. This begs the question of whether this decline can be attributed to public policies designed to this end. ${ }^{\mathrm{I}}{ }^{8}$

\begin{tabular}{|c|c|c|c|}
\hline Year & Occupied Workers & Informal & $\%$ \\
\hline I999 & 69.143 .254 & 31.596 .285 & 45,7 \\
\hline $200 I$ & 73.522 .903 & 33.933 .943 & 45,3 \\
\hline 2003 & 77.544 .872 & 34.668 .495 & 44,7 \\
\hline 2005 & 85.225 .154 & 37.122 .778 & 43,6 \\
\hline 2007 & 89.185 .678 & $37.4 \mathrm{II} .883$ & $4 \mathrm{I}, 9$ \\
\hline 2009 & 9I.43I.443 & 36.889 .6 Iо & 40,3 \\
\hline $201 \mathrm{I}$ & 92.465 .640 & 35.479 .844 & 38,4 \\
\hline 2013 & 96.659 .379 & 35.472 .544 & 37,0 \\
\hline
\end{tabular}

Table I

Evolution of informality rate in the Brazilian labor market (occupied population age 15 and above) $1999-2013^{19}$

Source: PNAD

\section{POLICIES COMBATTING INFORMALITY:} DESIGN AND EFFECTIVENESS

The federal government has built, in the past two decades, a broad repertoire of policies aimed at enhancing the income of more vulnerable segments of the population. A large fraction of this repertoire is under the responsibility of the Ministry of Labor and Employment (Ministério do Trabalho e Emprego - MTE), in charge of executing and overseeing several legal instruments instituted in the last two decades or so. These instruments acknowledge the many facets of informality, which also require actions that are also multiple, and can be grouped into the following three lines:

a) policies aimed at the oversight and enforcement of the legislation and the formalization of labor contracts (such as labor inspection);

b) flexibilization of labor regulations;

c) policies aimed at increasing the number of jobs and income generation, comprising a varied array of initiatives, from microcredit to tax simplification, and including tax breaks of different kinds and minimum wage increases.

Since there is not enough space here to analyze all policies, I shall concentrate on those directly aimed at "combatting" (or reducing) informality. ${ }^{20}$ 


\section{INCOME GENERATION AND JOB CREATION}

In line with the changes in how international agencies perceived informality, especially in Latin America, Brazil has slowly built the idea that informality is a structural component of our economic dynamics and that the best form of "taming" or "combatting" it is by opening up job opportunities for workers and informal entrepreneurs to improve their income, working conditions and enterprises. Also given the academic literature linking the amount of taxes incurred by businesses and entrepreneurship indicators (for example, Djankov et al., 2010), Brazil has developed an important set of measures that encourage small businesses. Among them, there are actions targeting regulation and the financing of micro, small and medium-sized businesses (MPME), individual micro-entrepreneurs (MEI), policies of income distribution and others. Those policies aimed at reducing the cost of formalization, and the generation of incentives for permanence in formality. In the next section, I conduct a review of the main programs and their results.

\section{REGULATION OF MPMES}

In 2006, the Federal Government created the Simples Nacional (The National Simple Program), aimed at the reduction of taxes and the simplification of bureaucratic procedures for micro, small and medium-sized businesses. The Simples Nacional unifies eight federal, state, and municipal level taxes into a single payment slip, reducing bureaucracy and taxing incidence by $40 \%$. The tax bracket varies according to turnover and the economic sector. Micro-sized companies (which yield up to I 80 thousand Brazilian Reais) must pay between $4 \%$ and $6.5 \%$ of their turnover per year, depending on the sector, while eligible companies within the upper bracket of the program (up to 3,6 million Brazilian Reais per year) may pay up to $25 \%$, depending on the sector. ${ }^{21}$

In 2008 , within the Simples Nacional program, a category called Individual Micro-Entrepreneur (Microempreendedor Individual - MEI) was created and defined as "a person who is self-employed and becomes legalized as a small businessperson." ${ }^{22}$ Pursuant to Complementary Law n. I 28 (December I9, 2008), those who qualify for MEI cannot have turnovers exceeding 60 thousand Brazilian Reais per year and cannot be a partner in another business as an associate or owner. The MEI can employ one person and pay minimum wage or the minimum established according to the professional category. Upon enrollment, the worker is registered in the National Listing of Juridical Persons (Cadastro Nacional de Pessoas Jurídicas - CNPJ), which entitles her to open a business bank account and enter the universe of government-subsidized credit. In addition, the MEI is exempt from federal taxes (Income Taxes, PIS, Cofins, IPI and CSLL). The cost of maintaining this status is the monthly payment of a fee (40.40 Brazilian Reais in the case of commerce and industry; 44.40 Brazilian Reais in the case of services; or 45.40 Brazilian Reais for commerce and ser- 
vices). This money is allocated to Social Security and the funds linked to the taxes on the sales of goods and services (ICMS) and services, respectively a state and municipal-level taxation. These numbers are updated on a yearly basis, according to variations of the minimum wage. With these contributions, the MEI is granted access to social benefits such as paid maternity leave, paid sickness leave and retirement.

In other words, the policies has a threefold effect: (I) it reduces to zero the cost of entry in formality; (II) it considerably lowers the cost of permanence in formality (0.9\% or less of the annual turnover of those within the 60 thousand Brazilian Reais bracket); (III) offers important incentives to workers who previously were not covered by the public pension or health system.

The Federal Government stipulated eligible sectors of the economy based on the National Classification of Economic Activities (CNAE), and most of those selected are concentrated in the subsectors of commerce and services, or those that combine these with micro-industrial activities. In other words, only workers from selected sectors can enroll as a MEI. In 20II, the number of selected sectors was significantly expanded, encompassing close to $70 \%$ of the economic activities listed by the CNAE.

These two mechanisms (the Simples and the MEI) drastically reduced the costs of formalizing, in addition to offering opportunities of access to the financial system, and in the case of the MEI, the benefit of pension system coverage. The success of the measure is, however, the object of controversy. Indeed, in 20I 2, there were 7 million people enrolled in the Simples Nacional, a number that climbed to 9,2 million in September 20I4, according to data provided by the Federal Income System. Of the latter, approximately 6,2 million (or two-thirds) were MEI, of which 4,5 million entered the system directly through an internet gateway created (the Portal do Empreendedor), meaning that they had not been entrepreneurs before, and another I,7 million enrolled as MEI after leaving another entrepreneurial classification. It is undeniable that the new legislation attracted new entrepreneurs and reconfigured the status of those previously enrolled in the Simples, although it is still not clear what the true impact on informality has been.

Let us take, for example, the contributions towards the pension system by autonomous workers and employers. In 2008 only I out of each 6.3 autonomous workers were covered. Among the employers with one employee, protection was assured in only half of all cases. Five years later, one out of four autonomous workers were protected and almost two out of three micro-entrepreneurs. This translated into more than 2 million autonomous workers and microentrepreneurs being removed from informality in the span of 5 years, through entry in the pension system, something that must be assumed as an indicator (albeit indirect) of adhesion to the mechanisms of formalization with the Simples and MEI. This is what Table 2 suggests. One can note the drop in the num- 
ber of employers with one employee during the period. And we know, from the same source of the table, that the number of employers with two or three employees has increased. It is probable that a migration from one category to another occurred, also indicating a shift towards greater formalization. ${ }^{23}$

\begin{tabular}{l|l|r|r|r}
\hline \multicolumn{2}{|c|}{} & Contributors & \multicolumn{1}{c|}{ Number } & Total occupied population \\
\hline \multirow{2}{*}{2008} & Self-employed & I5,8\% & 2.950 .430 & I8.728.540 \\
\cline { 2 - 5 } & Employer with one employee & $45,9 \%$ & 534.490 & I.163.646 \\
\cline { 2 - 5 } & Total & $17,5 \%$ & 3.484 .920 & I9.892.186 \\
\hline \multirow{2}{*}{2013} & Self-employed & $25,5 \%$ & $5.073 .38 \mathrm{I}$ & I9.868.867 \\
\cline { 2 - 5 } & Employer with one employee & $60,3 \%$ & 54 I.8I4 & 894.149 \\
\cline { 2 - 5 } & Total & $\mathbf{2 8 , 0 \%}$ & 5.615 .195 & 20.763 .016 \\
\hline
\end{tabular}

Table 2

Evolution of rate of pension contribution among self-employed workers and employers with a single employee. Individuals aged 5 or more.

Brazil, 2008 and 2013

Source: PNAD

Be it as it may, costs of formalization were reduced to almost zero, in the case of the MEI, and considering that the cost of remaining in informality is low, we must inquire why adhesion, at least until 2013, was so low (only one-fourth of those self-employed contributed towards the pension system). I would like to suggest that part of the explanation has to do with the notion "informal sociability," a distinguishing trait of the social and economic environment of most of these entrepreneurs, especially the poorer ones, as discussed in the first part of this study. I will return to this matter in the conclusion. ${ }^{24}$

\section{MINIMUM WAGE AND INFORMALITY}

It is part of the conventional wisdom of economic literature that increases in minimum wage lead to a reduction of formal jobs and, consequently, an increase of informality and unemployment. ${ }^{25}$ In the case of Latin America and Brazil, in particular, much of the literature was produced during the years of neo-liberal adjustments, ${ }^{26}$ and are in line with the recommendations of international agencies (such as the IMF and the World Bank), towards the flexibilization of labor relations, in order to thereby reduce the negative impacts of neoliberalism on labor market indicators (employment, income, formality rate etc.). The public policy recommendations, in this context, almost invariably point towards minimum wage as an element that conducts to rigidity in labor 
markets, suggesting that it be pegged at levels (usually low ones) that will ensure equilibrium between labor supply and demand.

In recent years, however, the Brazilian case has offered evidence in the opposite direction, meaning that it is possible to (substantially) increase the minimum wage and at the same time generate formal jobs and reduce informality (Chart I). The chart suggests that the increase in the mass of salaries that derives from real increases of the minimum wage benefits informal economic activities, as a result of greater demand for their services and products (see Oliveira, I987: 85-89), ultimately increasing the income of informal workers and also their disposition to formalize their businesses or activities. The association of this general mechanism with policies of reduction of the costs of formalization (such as those discussed in previous sections) seems virtuous, or at least it has been so until economic crisis that struck after 20 Io.

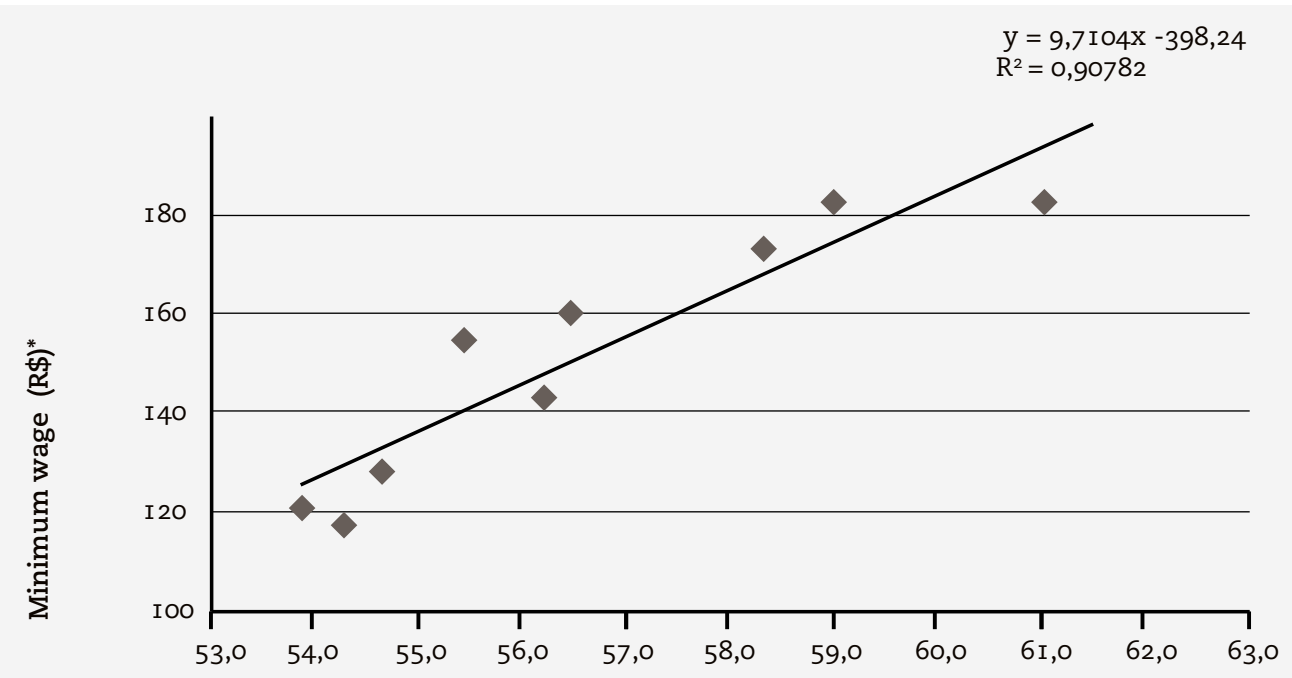

Formality rate

Chart I

Relationship between the growth of minimum wage and informality rates

Brazil, 2003-20I 2

Sources: Institute of Studies of Work and Society (IETS) for the formality rate;

Panorama Laboral (2014) for real minimum wage in Brazil 
Stated otherwise: the hypothesis these data seem to suggest is that the reduction of the costs of formalizing informal businesses as well as the reduction of costs of remaining in the formal world (which guided the institution of the MEI) were efficient in the reduction of informality because they were undertaken, also, in an environment in which lower-income classes received a major boost in their consumption capacity, as a result of the increase of the minimum wage and of average real income in the economy, which provided the safety cushion for self-employed workers to bear the costs of making themselves visible to the State through formalization. This hypothesis cannot be tested directly here, but must be part of any in-depth discussion regarding policies aimed at reducing informality.

\section{CONCLUSION}

The many policies designed in Brazil in the last years seemed to have contributed towards the reduction of informality, both in relative and absolute terms. Nevertheless, informality remains the main form of achieving the means of living of almost $40 \%$ of the population. Even though millions have been removed from this condition, there are still millions of others that will fail to be reached by any specific policy, simply because their entire sociability was formed in the realm of informality. Housing, access to electricity and other urban infrastructure, social relations, and the relationship with the State everything is informal. As are the businesses of those who own one. There are no taxes to be paid and, more often than not, all urban facilities are also accessed illegally, especially electric power, plumbing, and information technology (such as cable television and the internet). Formalizing a business does not mean exclusively becoming integrated into social security, for example. It chiefly means becoming visible from the State's point of view and facing higher costs for the maintenance of one's small informal business, jeopardizing its sustainability. ${ }^{27}$ Furthermore, a considerable portion of these small informal entrepreneurs is suspicious of public agents, microcredit providers, NGOs and other entities that try to support them. What is more, a large number of salaried workers without signed labor cards are in this situation because their employers are in informality, rendering this segment of the informal world very resistant to public policy.

Income distribution policies (especially minimum wage increases, but also, in the poorer regions of Brazil, the Bolsa Familia program) seem to have produced a significant impact on the reduction of informality through the increase of the mass of salaries and the purchase power and consumption capacity of the poorer, a fraction of which goes to the pockets of informal entrepreneurs in commerce, personal services and maintenance, and also civil construction. The increase of income and well-being of these entrepreneurs, in combination with the policies aimed at reducing the cost of for- 
malization, can be driving the shift detected in Chart I, above, especially after the second round of measures aimed at reducing the costs of remaining formalized. This hypothesis, however, requires further investigation - yet its plausibility can be sustained by the data presented in Graph I.

Received 02/18/2016 | Approved 04/13/2016

Adalberto Cardoso holds a PhD in Sociology from the University of São Paulo (USP), and is a professor and researcher at the Institute of Social and Political Studies of the State University of Rio de Janeiro (IESP-UERJ). His research lies in the fields of the sociology of work, urban sociology, social inequality, and social theory. He has recently published Brazil emerging: inequality and emancipation (20I4), organized with Jan Nederveen Pieterse; and Ensaios de sociologia do mercado de trabalho brasileiro (2013); A construção da sociedade do trabalho no Brasil: uma investigação sobre a persistência secular das desigualdades (2010). In 2016 will appear Work in Brazil: essays in economic and historical sociology. 


\section{NOTES}

I See project FORLAC: <http://ilo.org/americas/temas/ econom\%C3\%ADa-informal/lang--es/index.htm>.

2 An excellent study on the interaction between different vectors of formalization in Brazil is Krein \& Manzano (20I4). The note available at the ILO website is an executive summary of the article, to which I had access thanks to the generous offer by José Dari Krein, to whom I am thankful.

3 According to Palmer (2004: 7), Keith Hart presented his ideas to colleagues at the Institute of Development Studies (IDS, UK) for the first time in I97I, the result of research carried out in Ghana between 1965 and 1968. Among audience members, Hans Singer and Richard Jolly, who would lead the ILO mission to Kenya in I972. Machado da Silva (I97I) was the first to identify a "non-formal" sector in urban areas in peripheral capitalism, the characteristics of which are the same as the ILO's 1972 informal sector.

4 See Lewis (I96I), Nun (I969), Quijano (I970, I978), Paoli (I973), Touraine (1977), among others.

5 The most polished formulation of this argument was made by Granovetter (1974), who returns and develops the idea later in Granovetter (I988).

6 This notion of social class is owed to Bourdieu (I979), and also Bourdieu (i989: cap. VI).

7 And also in most of the rural world, where pure subsistence, obtained through the means of production outside the Market, is also a thing of the past in most countries in the region. Likewise, economies based on bartering and the gift cannot be generalized in the urban world, nor are capable of providing the infrastructure for survival.

8 Since Simmel (I978: chapter. 6) we know that culture, a central aspect of the identity construction process, is also converted into a commodity, just as in Brazil good education and quality health services have become commodities. As a result, the construction of the dispositions of actions, which constitute the core of our social identity (Lahire, 2006) is, largely, mediated by the market and, in this sense, privatized. 
9 The employment crisis of the Ig9os in Brazil (Pochmann, 200I; Pastore, 1997) and in the rest of the world (Rifkin, I996) generated everywhere grievances for social protection and rekindled the dream of salaried work regulated by the State, which was always within the horizon of migrant workers in the country (Cardoso, 2010), but which intensely competed with the desire to achieve autonomy and establish oneself independently.

During the privatizations of the Ig9os in Brazil, many workers sent off from state-owned companies, often through "voluntary dismissal programs" offering different sorts of monetary incentive, nurtured (and sponsored) the dream of becoming independent. Research on the frustration of such projects is abundant, and nostalgia for protected, salaried work is identified as a constant. See Gomes (2002) and Piñaranda et al. (2006).

I I Analyzing the data collected from the Life Patterns Survey conducted in the first decade of the 2000s, Santos (2006), concluded that the horizon of a "good life" for the average Brazilian was an income of $\mathrm{R}$ \$, 000 (approximately 850USD, considering the Exchange rate in December 2014).

I 2 In a not so recent review of the concept Cacciamali (2007) qualifies as Marxist the interpretations of the "Informal Sector" (she uses upper case for the term) that comprehend it as the set of interstitial activities embedded in capitalistic economic activity, which can be destroyed by accumulation or reproduced as a complement to other key activities of the economy. The recent experience of "pacification" of favelas in Rio de Janeiro is an example of the penetration of capitalistic forms of accumulation in areas formerly the exclusive province of informal or illegal enterprise.

I3 For the Mexican case, see Pries (1992). For an aggregate study on Brazil see Cardoso, Guimarães \& Comin (2006)

I4 In the Brazilian labor Market (and also in the majority of Latin American countries), there is a set of people that are and will probably remain in occupations that will very likely never be "formalized." Among them, men who are too "old": someone who loses his formal job at 45 will hardly find another registered job, as shown by Cardoso (2013). There are also women of "advanced" age, who 
spend their lives working as maids or in other precarious jobs in commerce or the services sector, who are unable of finding occupation other than unregistered or selfemployed work. There are people who will never find salaried, regulated or unregulated, work.

I5 As argued by Cacciamali (2000), Sassen (2000), Dombois (2012), among others.

I6 In other words, informality as necessity, opportunity, or choice, or the residual outcome of precarious life trajectories.

I7 This definition is found in the majority of studies on the "informal sector" in Brazil. See for example, (2007), Pochmann (2012), Pastore (1997), Coletto (2010), Dedecca (2007). Starting in 20I I, the National Survey by Household Samples (Pesquisa Nacional por Amostra de Domicílios - PNAD) included in its basic questionnaire some questions directed to employers and self-employed workers concerning the status of their enterprises (whether they offer receipts, are registered in the CNPJ, perform professional accounting and others). The questions will allow for the construction of historical series to hew more closely to the real world of informality, which has so far only been described as a result of approximations derived from traditional statistics.

I8 The decline can have other causes, such as a generational effect (older aged informal workers abandoning activity), the reduction of the rate of informality, unemployment (with more informal workers becoming unemployed) etc., which would have the same effect as reducing informality in absolute terms.

I9 This indicator is comprised of: I) salaried workers without signed labor cards (including domestic workers); 2) selfemployed workers who do not contribute towards social security; 3) employers with one employee who do not contribute towards social security.

20 For labor inspection see Cardoso \& Lage (2007). An excellent study on the flexibization of labor legislation in Brazil is Voguel (2013). Bensusán (2006) contests the theories that call for flexibilization as the solution to create jobs and reduce informality in Latin America. 
2I See <http://www.sebrae.com.br/sites/PortalSebrae/artigos/Mudan\%C3\%A7as-no-Supersimples:-o-que-o-donode-pequeno-neg\% $\mathrm{C}_{3} \%$ B3cio-deve-saber $>$. Accessed May 2016.

22 See <http://www.portaldoempreendedor.gov.br/mei-microempreendedor-individual>. Accessed May 2016.

23 Another piece of evidence in the same direction is presented by Rocha, Ulyssea \& Rachter (20I4).

24 Policies aiming at formalization by means of employment generation and job creation, as stated above, focus on two vectors: reducing formalization costs; and reducing costs and creating incentives for the worker to remain in the formal labor realm. In an addendum to relief measures and simplification of regulation of entrepreneurship, the federal government expanded existing microcredit supply mechanisms, and created new ones, injecting a substantial amount of resources in the informal economy, hoping to thereby expand the formalization of enterprises. The Employment and Income Generation Program (PROGER) is one of those mechanisms. Since this is not the place to discuss the topic, I draw the reader's attention to MTE (2012) and the evaluation of its effects on the formalization of the jobs carried out by FIPE (2012). Another important policy is the National Program of Oriented Productive Microcredit (Programa Nacional de Microcrédito Produtivo Orientado - PNMPO), created in April 2005, targeted at informal micro entrepreneurs.

25 In this direction, Mazumdar (1989), Harrison \& Leamer (1997), Perry et al. (2007: chap. 4). Ghellab (I998), for example, found that after a $10 \%$ increase of the minimum wage in Ghana, the informal sector grew $1,4 \%$. For the case of Indonesia see Comola \& Mello (2010).

26 For the case of Chile see Wedenoja (2013). In a similar vein concerning Brazil (from I982 to 2002) see Carneiro (2004). For the case of Colombia, see Maloney \& Mendez (2004).

27 In Brazil this is the case of the SEBRAE (Serviço Brasileiro de Apoio à Pequena e Média Empresa), a semipublic entity that offers training and logistical support for small and micro-sized enterprises. 


\section{BIBLIOGRAPHY}

Barbosa, Alexandre de F. (20II). O conceito de trabalho informal, sua evolução histórica e potencial analítico atual: para não jogar a criança fora junto com a água do banho. In: Oliveira, Roberto Véras de et al. (eds.). Marchas e contramarchas da informalidade do trabalho. Das origens às novas abordagens. João Pessoa: Editora Universitária, p. I05-I59. Bensusán, Graciela. (2006). Las instituciones laborales en perspectiva comparada. In: Bensusán, Graciela (ed.). Diseño legal y desempeño real: instituciones laborales en América Latina. México city: UAM/Porrúa, p. 4II-497.

Botero, Juan C. et al. (2004). The regulation of labor. The Quarterly Journal of Economics, II9/4, p. I339-I382.

Bourdieu, Pierre. (1979). La distinction. Paris: La Découverte. Bourdieu, Pierre. (1977). Outline of a theory of practice. Cambridge: Cambridge University Press.

Bruhn, Miriam \& McKenzie, David. (2014). Entry regulation and the formalization of microenterprises in developing countries. The World Bank Research Observer, 29/2, p. I86-20I.

Cacciamali, Maria C. (2007). (Pré-)conceito sobre o setor informal, reflexões parciais embora instigantes. Econômica, 9/I, p. I45-I68.

Cacciamali, Maria C. (2000). Globalização e processo de informalidade. Revista Economia e Sociedade, I4, p. I53-I74. Cacciamali, Maria C. (1982). Um estudo sobre o setor informal urbano e formas de participação na produção. Doctoral Thesis. Faculdade de Economia, Administração e Contabilidade/ Universidade de São Paulo.

Cardoso, Adalberto M. (2014). Sindicatos no Brasil: passado, presente e futuro. In: Cattani, Antônio D. (ed.). Brasil, Horizonte 202I. Porto Alegre: Escritos.

Cardoso, Adalberto M. (2013). Ensaios de sociologia do mercado de trabalho. Rio de Janeiro: Ed. FGV.

Cardoso, Adalberto M. (20Io). A construção da sociedade do trabalho no Brasil: uma investigação sobre a persistência secular das desigualdades. Rio de Janeiro: Ed. FGV.

Cardoso, Adalberto M.; Guimarães, Nadya A. \& Comin, Álvaro A. (2006). Os deserdados da indústria. Reestruturação produtiva e trajetórias interssetoriais de trabalha- 
dores demitidos da indústria brasileira. In: Guimarães, Nadya \& Hirata, Helena (eds.). Desemprego: trajetórias, identidades, mobilizações. São Paulo: SENAC, p. 45-90.

Cardoso, Adalberto \& Lage, Telma. (2006). Diseño legal y desempeño real: Brasil. In: Bensusán, Graciela (org.). Diseño legal y desempeño real: instituciones laborales en América Latina. México city: UAM/Porrúa, p. 167-239.

Carneiro, Francisco G. (2004). Are minimum wages to blame for informality in the labour market? Empirica, 3I, p. 295-306.

Castel, Robert. (I998). As metamorfoses da questão social: uma crônica do salário. Petrópolis: Vozes.

Castelo Branco, Elizabeth et al. (20I4). Avaliação do programa Crediamigo: melhoria das condições de vida. Informe técnico do ETENE, I/I, julho. Salvador: Banco do Nordeste do Brasil. Available at: < http://www.bnb.gov.br/ documents/80786/206522/artigo_avaliacao_crediamigo_ ITAPP_OI_oI.pdf/oec4odcc-c436-4ao5-b4f3-73aegd3dfb39>. Accessed I Aug. 2016.

Coletto, Diego. (2010). The informal economy and employment in Brazil. New York: Palgrave Macmillan.

Comola, Margherita \& Mello, Luiz de. (2010). How does decentralized minimum wage setting affect employment and informality. Available at: <http://www.parisschoolofeconomics.com/comola-margherita/pdf/paperMW.pdf>. Accessed I Aug. 2016.

Costa Ribeiro, Carlos A. (2009). Desigualdade de oportunidades no Brasil. Belo Horizonte: Argvmentvm.

Costa Ribeiro, Carlos A. (2007). Estrutura de classe e mobilidade social no Brasil. Bauru, SP: EDUSC/ANPOCS.

Costa, Fernando N. (20I0). Microcrédito no Brasil. Texto para Discussão, I75. IE/UNICAMP. Available at: <http://www. eco.unicamp.br/docprod/downarq.php?id=I805 \&tp =a $>$. Accessed I Aug. 2016.

Dedecca, Claudio S. (2007). Setor informal e informalidade no Brasil. Ciência Hoje, 234, p. I8-23.

Djankov, Simeon et al. (2010). The effect of corporate taxes on investment and entrepreneurship. American Economic Journal: Macroeconomics, 3/2, p. 3I-64. 
Dombois, Rainer. (20I2). "Brasilianización” global? Empleo atípico y regímenes de bienestar en Europa y América Latina. Revista Latino-Americana de Estudos do Trabalho, I $7 / 28$, p. 7-43.

Filgueiras, Luiz; Druck, Graça \& Amaral, Manoela F. (2004). O conceito de informalidade: um exercício de aplicação empírica. Cadernos CRH, I7/4I, p. 2II-229.

FIPE. (2OI2). Avaliação do PROGER: resultados e perspectivas. São Paulo: LTr. Available at: <ftp://ftpdtp.mte.gov.br/pub/ proger/AVALIACAO_EXTERNA_DO_PROGER_FIPE_RESULTADOS_E_PERSPECTIVAS.pdf $>$. Accessed I Aug. 2016.

Fischer, Brodwyn. (2014). A century in the present tense: crisis, politics, and the intellectual history of Brazil's informal cities. In: Fischer, Bordwyn; McCann, Bryan \& Auyero, Javier (eds.). Cities from scratch. Poverty and informality in urban Latin America. Durham: Duke University Press, p. 9-67. Gomes, Soledad E. A. (2002). Empregabilidade em tempos de crise. Doctoral Thesis. PPGSA/IFCS/Universidade Federal do Rio de Janeiro.

Granovetter, Mark. (1988). The sociological and economic approaches to labor market analysis: a social structural view. In: Farkas, George \& England, Paula (eds.). Industries, firms and jobs: sociological and economic approaches. New York: Plenum Press, p. I87-216.

Granovetter, Mark. (1974). Getting a job. Cambridge: Cambridge University Press.

Guimarães, Nadya A. (2004). Caminhos cruzados: estratégias de empresas e trajetórias de trabalhadores. São Paulo: Ed. 34. Harrison, Ann \& Leamer, Edward. (I997). Labor markets in developing countries: an agenda for research. Journal of Labor Economics, I5/3, p. I-I9.

Hart, Keith. (2006). Bureaucratic form and the informal economy. In: Guha-Khasnobis, Basudeb.; Kanbur, Ravi. \& Ostrom, Elinor. (eds.). Linking the formal and informal economy: concepts and policies. Oxford: Oxford University Press, p. 32-5I.

Hart, Keith. (1973). Informal income opportunities and urban employment in Ghana. Journal of Modern African Studies, II/3, p. 6I-89. 
Harvey, David. (20II). O enigma do capital e as crises do capitalismo. São Paulo: Boitempo.

IBASE. (I999). Democracia viva, edição especial: Geração de emprego e renda. Rio de Janeiro: IBASE. Available at: <ftp:// ftpdtp.mte.gov.br/pub/proger/Resultados_da_Avaliacao_ do_PROGER_Revista_Democracia_Viva_Novembro_I999. pdf $>$. Accessed I Aug. 2016.

ILO. (2002). Women and men in the informal economy: a statistical picture. Geneva: ILO.

ILO. (I972). Employment, incomes and equality: a strategy for increasing productive employment in Kenya. Geneva: ILO. Available at: <http://wiego.org/publications/employment-incomes-and-equality-strategy-increasing-productive-employment-kenya>. Accessed I Aug. 2016.

Krein, José Dari \& Manzano, Marcelo. (2014). Notas sobre formalización. Estudios de caso: Brasil. Santiago: OIT. Available at: <http://ilo.org/wcmsp5/groups/public/---americas/---ro-li $\mathrm{ma} /$ documents/publication/wcms_248256.pdf $>$. Accessed I Aug. 2016.

Lahire, Bernard. (2006). A cultura dos indivíduos. Porto Alegre: Artmed.

Lautier, Bruno. (2004). L'économie informelle dans le Tiers Monde. Paris: La Découverte.

Lewis, Oscar. (I96I). The children of Sanchez. Autobiography of a Mexican family. New York: Random House.

Lin, Nan. (200I). Social capital: a theory of structure and action. London/New York: Cambridge University Press.

MTE. (20I5). Informações gerenciais do Programa Nacional de Microcrédito Produtivo Orientado. Brasília: MTE.

MTE. (20I2), Informações gerenciais do Programa de Geração de Emprego e Renda. Brasília: MTE. Available at: <ftp://ftpdtp.mte.gov.br/pub/proger/o6_INFORME_PROGER_AGOSTO_DE_2OI2.pdf >. Accessed I Aug. 2016.

Machado da Silva, Luiz A. (I97I). Mercados metropolitanos de trabalho manual e marginalidade. Dissertação de mestrado. PPGAS/ Museu Nacional, Universidade Federal do Rio de Janeiro.

Machado da Silva, Luiz A. (2002). Da informalidade à empregabilidade: reorganizando a dominação no mundo do trabalho. Cadernos CRH, I5/37, p. 8I-Io9. 
Maloney, William \& Mendez, Jairo. (2004). Measuring the impact of minimum wages: evidence from Latin America. In: Heckman, James J. \& Pagés, Carmen (eds.). Law and employment: lessons from Latin American and the Caribbean. Chicago: University of Chicago Press, p. I09-I30.

Mazumdar, Dipak. (1989). Microeconomic issues of labor markets in developing countries: analysis and policy implications. An Economic Development Institute of The World Bank Seminar Paper, 40. Available at: <http://documents. worldbank.org/curated/pt/90590I468766I858Ig/pdf/multi-page.pdf $>$. Accessed I Aug. 2016.

Monteiro, Joana C. M. \& Assunção, Juliano J. (20I2). Coming out of the shadows? Estimating the impact of bureaucracy simplification and tax cut on formality in Brazilian microenterprises. Journal of Development Economics, 99/I, p. I05-II5.

Neri, Marcelo C. (ed.). (2009). Microcrédito, o mistério nordestino e o Grameen brasileiro: perfil e performance dos clientes do CrediAmigo. Rio de Janeiro: Ed. FGV.

Nun, José. (200I). Marginalidad e exclusión social. Buenos Aires: Fondo de Cultura Económica.

Nun, José. (1969). Superpoblación relativa, ejército industrial de reserva y masa marginal. Revista Latinoamericana de Sociología, 5, p. I78-235.

Oliveira, Francisco de. (1987). O elo perdido. Classe e identidade de classe. São Paulo: Brasiliense.

Oliveira, Francisco de. (I972). A economia brasileira: crítica da razão dualista. Estudos Cebrap, 2, p. 3-82.

Oliveira, Roberto Véras de. (20II). Para discutir os termos da nova informalidade: sobre sua validade enquanto categoria de análise na era da flexibilização. In: Oliveira, Roberto Véras de; Gomes \& Targino, Ivan (eds.). Marchas e contramarchas da informalidade do trabalho. Das origens às novas abordagens. João Pessoa: Editora Universitária, p. I9I-227.

Palmer, Robert. (2004). The informal economy in Sub-Saharan Africa: unresolved issues of concept, character and measurement. Occasional Papers, 98. Centre of African Studies, Edinburgh University. 
Paoli, Maria Celia P. M. (I973). Trabalho e marginalidade: um estudo de caso. Revista de Administração de Empresas, I3/3, p. II3-I34.

Pastore, José. (1997). A agonia do emprego. São Paulo: LTr. Pastore, José \& Silva, Nelson do Valle. (2000). Mobilidade social no Brasil. São Paulo: Makron Books.

Perry, Guillermo et al. (eds.). (2007). Informality: exit and exclusion. Washington: The World Bank.

Piñaranda, Fabiana et al. (2006). Respeito: a construção do conceito a partir das trajetórias laborais dos desligados de estatais. Anais do X Colóquio Internacional sobre Poder Local. Salvador. Available at: <nupet.iesp.uerj.br/arquivos/ Pinaranda.pdf $>$. Accessed I Aug. 2016.

Pochmann, Marcio. (2012). Nova classe média? O trabalho na base da pirâmide social brasileira. São Paulo: Boitempo.

Pries, Ludger (1992). Movilidad en el empleo. Una contraposición de trabajo asalariado y por cuenta propria en Puebla/México. Serie Sociologia, S-I, p. 37-65.

Quijano, Aníbal. (1978). Notas sobre o conceito de marginalidade social. In: Pereira, Luiz (org.), Populações marginais. São Paulo: Duas Cidades, p. 38-6r.

Quijano, Aníbal. (1970). La formation du monde de la marginalite urbaine. Espaces et Societés, I, p. 7-26.

Rifkin, Jeremy. (I996). O fim dos empregos. São Paulo: Makron Books.

Rocha, Rudi; Ulyssea, Gabriel \& Rachter, Laísa. (2014). Do entry regulation and taxes hinder firm creation and formalization? Evidence from Brazil. Texto para Discussão ${ }^{\circ}$ I I. Instituto de Economia da UFRJ, Rio de Janeiro. Available at: <http://www.ie.ufrj.br/images/pesquisa/publicacoes/discussao/20I4/TD_IE_OII_2OI4_Rudi-v.2.pdf >. Accessed I Aug. 2016.

Santos, Wanderley G. dos. (2006). Horizonte do desejo. Instabilidade, fracasso coletivo e inércia social. Rio de Janeiro: Ed. FGV.

Santos, Wanderley G. dos. (I979). Cidadania e justiça. Rio de Janeiro: Campus.

Sassen, Saskia. (2000). The demise of Pax Americana and the emergence of informalization as a systemic trend. In: 
Tabak, Faruk \& Crichlow, Michaeline (eds.). Informalization: process and structure. Baltimore/London: Johns Hopkins University Press, p. 9I-II8.

Simmel, Georg. (1978). The philosophy of money. London: Routledge.

Simmel, Georg. (1968). The conflict in modern culture and other essays. New York: Teachers Press.

Souza, Paulo R. (I980). Empregos e salários em economias atrasadas. Doctoral Thesis. IE/Universidade Estadual de Campinas.

Telles, Vera da S. (2010). A cidade nas fronteiras do legal e ilegal. Belo Horizonte: Argvmentvm.

Theodoro, Mário L. (2000). As bases da política de apoio ao setor informal no Brasil. Texto para Discussão $n^{\circ} 762$. Brasília: IPEA.

Tokman, Victor E. (2004). Una voz en el camino. Empleo y equidad en América Latina: 40 años de búsqueda. Santiago: Fondo de Cultura Económica.

Tokman, Victor E. \& Souza, Paulo R. (1976). El sector informal urbano en América Latina. Revista Internacional del Trabajo, 94/3, p. II 2-I40.

Touraine, Alain. (1977). La marginalité urbaine. Boletín de Estudios Latinoamericanos y del Caribe, 22, p. 3-33.

Ulyssea, Gabriel. (2006). Informalidade no mercado de trabalho brasileiro: uma resenha da literatura. Revista de Economia Política, 26/4, p. 596-6r8.

Vogel, Luiz Henrique. (2013). Negociar direitos? Legislação trabalhista e reforma neoliberal no governo FHC (I995-2002). Rio de Janeiro: Eduerj.

Wedenoja, Leigh. (2013). The employment and wage effects of minimum wages in a context of informality and non-compliance: Evidence from Chile. Available at: <http:// www.sole-jole.org/I4420.pdf>.Accessed I Aug. 2016. 
Palavras chave

Informalidade;

Forma social do trabalho;

Brasil;

Políticas públicas; Mercado de trabalho.

Keywords

Informality;

Social form of work;

Brazil;

Public policies;

Labor market.

\section{INFORMALIDADE E POLÍTICAS PÚBLICAS PARA} COMBATÊ-LA. O CASO DO BRASIL

\section{Resumo}

O artigo parte da constatação de que muitas das recomendações de políticas públicas feitas por agências internacionais adotam perspectiva por vezes ingênua sobre a natureza da informalidade. Propõe-se uma abordagem inovadora da informalidade como uma forma social do trabalho que ganha contornos quando os trabalhadores se põem em movimento para obter meios de vida em ambientes nos quais quase tudo é informal (habitação, serviços de infraestrutura urbana, relações pessoais etc.). Depois de passar em revista as principais políticas adotadas pelo Brasil nos últimos anos para combater a informalidade, argumenta-se que parcela expressiva do "informal" jamais se formalizará, porque é resultado enraizado da experiência urbana de proporção significativa da população, que tem na informalidade seu elemento estruturante.

\section{INFORMALITY AND PUBLIC POLICIES TO OVERCOME IT. THE CASE OF BRAZIL}

\section{Abstract}

The article states that most of the policy recommendations made by international agencies adopt a sometimes naïve perspective about the nature of informality. It proposes an innovative approach that defines informality as a social form of work that is shaped when workers get on the move to obtain means of existence in environments where almost everything is informal (housing, urban infrastructure services, personal relationships etc.). After reviewing the main policies to combat informality adopted by Brazil in recent years, it argues that a significant portion of the "informal" will never formalize because it is rooted in the very urban experience of a significant proportion of the population, of which informality is a structuring element. 